\title{
Artificial nests conserve important native bees, Braunsapis spp. pollinating cashew
}

\author{
K. Vanitha* and T. N. Raviprasad \\ Crop Protection Section, ICAR-Directorate of Cashew Research, Puttur 574 202, India
}

\begin{abstract}
Native bees, Braunsapis picitarsis Cameron and Braunsapis mixta (Smith) are the common pollinators of cashew. Occupancy of both bee species was recorded within 15 days of installation of artificial nests made in wooden blocks as well as sticks of different plant species. Increased occupancy of bees in all nest holes was seen over time. Nest hole size of $3 \mathrm{~mm}$ diameter was highly preferred followed by 2.5 and $3.5 \mathrm{~mm}$ diameter. Out of total nests occupied, $80 \%$ and $14.71 \%$ were of 3 and $2.5 \mathrm{~mm}$ diameter hole size respectively, in the first year. During the second and third years also, higher occupancy was recorded in $3 \mathrm{~mm}$ diameter holes. The nests also assisted in recording the nesting behaviour and natural enemies of these bees.
\end{abstract}

Keywords: Artificial nest, Braunsapis spp., cashews, dried sticks, wooden blocks.

POLLINATION plays a key role in global biodiversity. One or more cultivars of $66 \%$ of the world's 1500 crop species are pollinated by insects, particularly bees ${ }^{1}$. These are the most specialized insects having morphological adaptation to collect, manipulate, transport and store pollen efficiently ${ }^{2}$, and they can be generalists to specialists. Besides honey bees, diverse native or wild bees are found in any cropping ecosystem. Native bees play a significant role in key pollination service for several crops and plants; however, they are often unnoticed or undervalued. Studies indicate that native bees could provide full pollination services even for a crop with heavy pollination requirements like watermelon, without the intervention of managed honey bees ${ }^{3}$.

Native bees have diverse requirements for the habitat and type of the substrate they use for their nest construction $^{4}$. Most bee species build their nests in soil, wood, hollow stems, pithy stems or pre-existing cavities and tunnels abandoned by other wood-boring insects.

Few bee species occupy artificial or trap nests successfully. Nesting resources have an important role in structuring bee communities ${ }^{5}$. Modern agricultural practices and increased urbanization pose a threat to these native bees. Scientists have estimated that globally one out of six bee species is regionally extinct, and more than $40 \%$

*For correspondence. (e-mail: vanis102@gmail.com) of bee species are vulnerable to extinction ${ }^{6}$. The possible reasons for decline in the population of bees could be exposure to pathogens, parasites and pesticides; habitat destruction; climate change; market forces; intra- and interspecific competition with native and invasive species, and genetic alterations ${ }^{7,8}$. Conservation and restoration of bee habitats are especially important to protect the native bee species ${ }^{3}$. However, little is known about the pollination services by wild bees, and the biotic and abiotic factors influencing nesting success or nesting site selection by different bee species ${ }^{9,10}$.

In cashew, pollination is effected by honey bees, and several native bees. A total of 13 bee species, including nine non-Apis bees were recorded as pollinators of cashew and their foraging behaviours have been documented $^{11}$. Among the native bees, Braunsapis spp. (Tribe: Allodapini, family: Apidae), viz. Braunsapis picitarsis (Cameron) and Braunsapis mixta (Smith) are quite common and abundant pollinators of cashew in Puttur, located in the west coastal region of Karnataka, India ${ }^{10}$. Braunsapis is a solitary stem-nesting bee, which provisions its larvae with pollen during development. Head width is more than $1.60 \mathrm{~mm}$ in $B$. picitarsis, and it is less than $1.60 \mathrm{~mm}$ in $B$. mixta ${ }^{12}$. During surveys in the plantations of ICAR-Directorate of Cashew Research (ICARDCR), Puttur, nests of these bees were found in dried sticks and pruned cut ends of cashew, mussanda, bamboo, etc. Unlike Ceratina sp., nests of Braunsapis spp. have no partitions, having nest entrance diameter between 1.5 and $3.0 \mathrm{~mm}$ and nest length from 1.00 to $12.5 \mathrm{~cm}$ (ref. 13). There are reports on certain stem nesting bees occupying artificial nests like bamboo sticks, drilled wooden blocks, etc. in a few countries ${ }^{14-17}$. However, there is a big gap in research on artificial bee nests in India. In this context, the present study was aimed to determine the possibility of using artificial nest sites for Braunsapis spp. to document their nesting behaviour and devise suitable conservation measures.

\section{Materials and methods}

The study was conducted in the cashew plantation of ICAR-DCR, Puttur, Karnataka. The region is a hilly track between the west coast and the Western Ghats of India, located at $12.77^{\circ} \mathrm{N}$ and $75.22^{\circ} \mathrm{E}$ at an average elevation of $87 \mathrm{~m}$. The vegetation cover of the study site is dominated 


\section{RESEARCH ARTICLES}

Table 1. Species of bees and wasps occupying the artificial bee nests at ICAR-Directorate of Cashew Research, Puttur

\begin{tabular}{|c|c|c|}
\hline Nest type & Bee species & Wasp species \\
\hline $\begin{array}{l}\text { Bamboo sticks (thin sticks having hollow } \\
\text { of } 2-4 \mathrm{~mm} \text { dia.) }\end{array}$ & $\begin{array}{l}\text { Braunsapis mixta****, } \\
\quad \text { Braunsapis picitarsis } * *\end{array}$ & $\begin{array}{l}\text { Pison } \mathrm{sp}^{* * *}, \text { Parancistrocerus } \mathrm{sp} . \\
\text { Chalybion bengalense }{ }^{* *}, \text { Chalybion } \mathrm{sp} .^{*}, \\
\text { Trypoxylon petiolatum }{ }^{*}\end{array}$ \\
\hline $\begin{array}{l}\text { Johnsons grass (thin sticks of } 4-5 \mathrm{~mm} \text { dia. } \\
\text { with or without pith) }\end{array}$ & B. mixta****, B. picitarsis* & $\begin{array}{l}\text { Pison sp.*, Parancistrocerus sp.*, } \\
\text { Carinostigmus costatus } *\end{array}$ \\
\hline Lantana (thin sticks of $4-6 \mathrm{~mm}$ dia.) & B. mixta**, B. picitarsis* & Carinostigmus costatus* \\
\hline Cashew (thin sticks of 4-6 mm dia.) & B. mixta**, B. picitarsis* & - \\
\hline Wooden block - holes of $2 \mathrm{~mm}$ dia. & - & Carinostigmus costatus $* * * *$ \\
\hline Wooden block - holes of $2.5 \mathrm{~mm}$ dia. & B. mixta**, B. picitarsis* & Carinostigmus costatus** \\
\hline Wooden block - holes of $3.0 \mathrm{~mm}$ dia. & B. mixta****, B. picitarsis $* *$ & $\begin{array}{l}\text { Parancistrocerus sp.*, Chalybion } \mathrm{sp}^{*}{ }^{*} \\
\text { Trypoxylon petiolatum } *\end{array}$ \\
\hline Wooden block - holes of $3.5 \mathrm{~mm}$ dia. & $\begin{array}{l}\text { B. mixta*** (in abandoned wasp nests) } \\
\text { B. picitarsis* (in abandoned wasp nests) }\end{array}$ & $\begin{array}{l}\text { Parancistrocerus sp. }{ }^{*} \text {, Chalybion bengalense*, } \\
\text { Chalybion sp.*, Trypoxylon petiolatum }{ }^{*}\end{array}$ \\
\hline Wooden block - holes of $4.0 \mathrm{~mm}$ dia. & $\begin{array}{l}\text { B. mixta* (in abandoned wasp nests), } \\
\text { B. picitarsis* (in abandoned wasp nests), } \\
\text { Tetragonula } \mathrm{sp} .\end{array}$ & $\begin{array}{l}\text { Parancistrocerus sp.*, Chalybion bengalense**, } \\
\text { Chalybion sp.* }\end{array}$ \\
\hline
\end{tabular}

****Abundant; ***More; **Moderate; *Less.

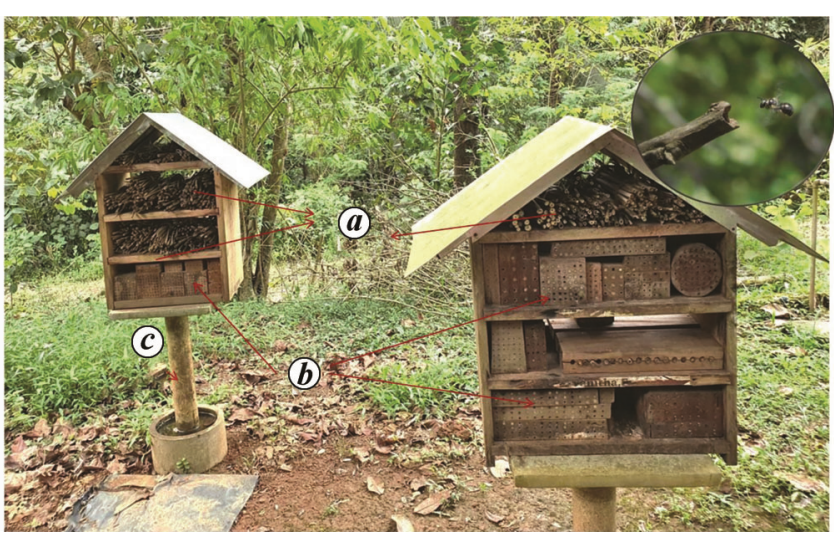

Figure 1. Artificial bee nest (Braunsapis mixta as insert). a, Sticks of bamboo, cashew, lantana and Johnson's grass. $\boldsymbol{b}$, Wooden blocks with drilled holes. $c$, Ant-well stand.
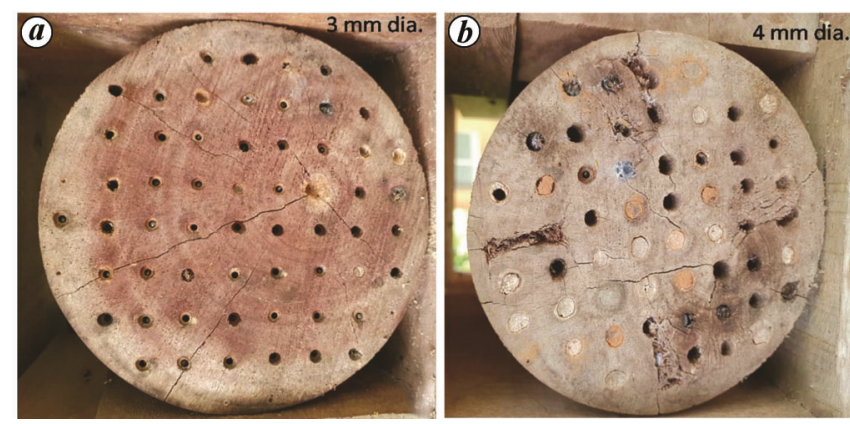

Figure 2. Bee occupancy in a cylindrical wooden block: $\boldsymbol{a}, 3 \mathrm{~mm}$ dia holes (more bees); $\boldsymbol{b}, 4 \mathrm{~mm}$ dia. holes (more wasps).

by cashew, but several weed species, including Chromolaena odorata, Mimosa sp., Vedalia trilobata, Tridox procumbens, Leucas aspera, Spermacoce sp., etc. are commonly found in the cashew plantations. In the vicinity of the study site, few other plants like arecanut, banana, coconut and wild trees are present. The temperature ranges from $16.0^{\circ} \mathrm{C}$ to $39.0^{\circ} \mathrm{C}$. The region receives heavy rainfall during the southwest monsoon between June and September with an annual mean rainfall of $3970 \mathrm{~mm}$. The relative humidity varies from $43 \%$ to $98 \%$ and is generally above $90 \%$ from June to November.

Wooden blocks of different shapes (cuboidal, cylindrical, cubical) and sizes belonging to mixed plant species were selected. Since the nest length of $B$. picitarsis was found to be between 1 and $12.5 \mathrm{~cm}$ (ref. 13), drill bits of $6 \mathrm{~cm}$ length and of different diameters were used for making drill holes in the wooden blocks. A series of smooth round holes $(6 \mathrm{~cm}$ deep and diameters of 2, 2.50, $3,3.50$ and $4 \mathrm{~mm}$ ) were made on one side of the wooden blocks. The holes were $1 \times 1 \mathrm{~cm}$ apart without any sharp edges. The wooden blocks were mounted on a wooden frame over an ant-well stand. Besides, bundles of cut stems or sticks of thin bamboo (hole diameter of 1.5$4 \mathrm{~mm}$ with a node in between), lantana, cashew and Johnson's grass of 25-30 cm length were also arranged in the wooden frame (Figure 1). In a cylindrical wooden block of $20 \mathrm{~cm}$ length, holes were made at both ends. To confirm the preference of hole size, at one end holes of 3 diameter were made, while $4 \mathrm{~mm}$ diameter holes were made at other end of the cylindrical wooden block (Figure 2). The whole set-up was kept adjacent to a cashew plantation of four acres during February 2018 when cashew trees were in full bloom; below a broadleaved tree to prevent direct mid-day sunlight and protection from rain. On the other side of the plot, different crops, including arecanut and banana were grown. The wooden blocks and sticks were observed regularly at fortnight intervals for the occupancy of bees or any other insects.

\section{Results and discussion}

Initially after installation of the nest, bees, including Tetragonula sp. and several wasp species, especially sphecids and crabronids started occupying the nest holes 

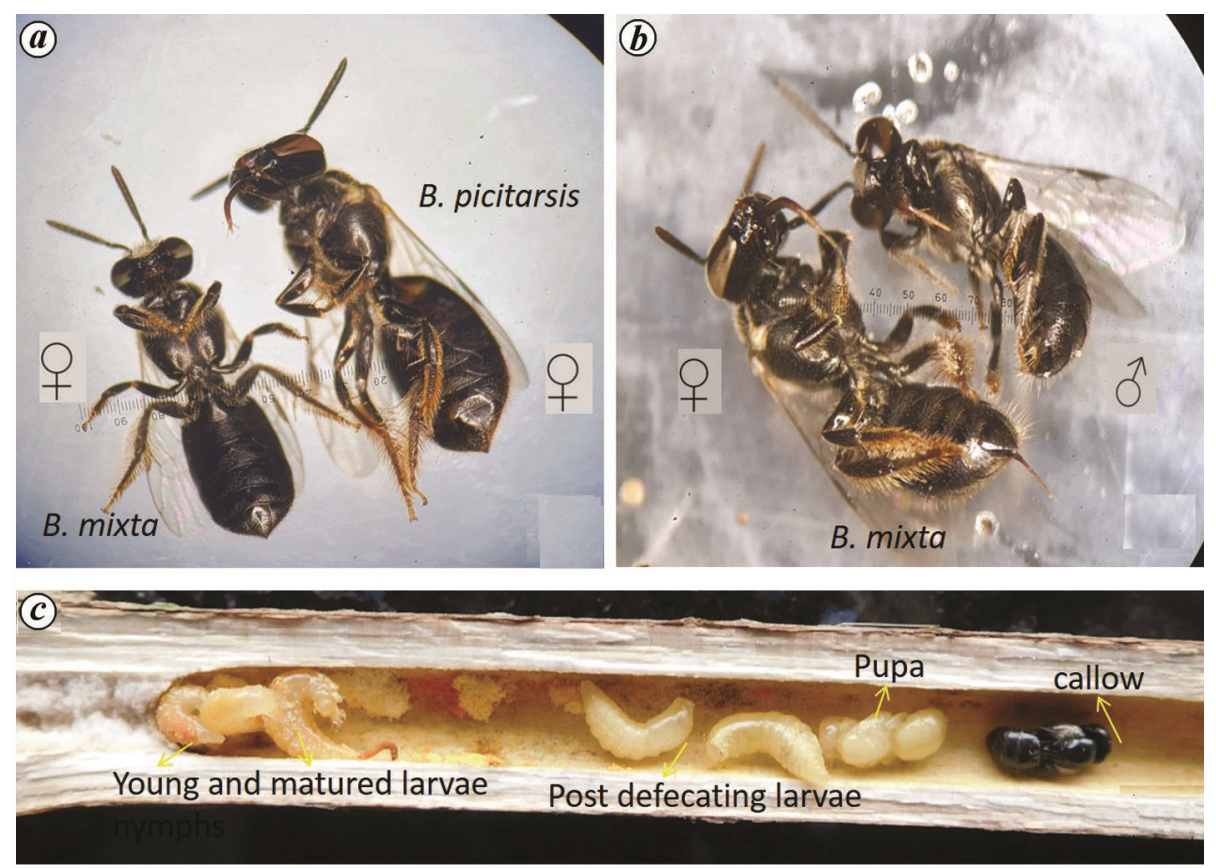

Figure 3. $\boldsymbol{a}$, Female bees of Braunsapis picitarsis and B. mixta. b, Male and female bees of B. mixta. $\boldsymbol{c}$, Developmental stages of $B$. mixta inside a cashew stick.

in the wooden blocks as well as the sticks. The bee species, B. picitarsis and B. mixta were observed in the nest holes within 15 days of installation of the nests. Bees of B. picitarsis are bigger compared to B. mixta. Figure 3 shows the developmental stages of male and female B. mixta. Initially, Tetragonula bees sealed few holes of $4 \mathrm{~mm}$ diameter with resin, but abandoned them within a short period. Tiny holes of $2 \mathrm{~mm}$ diameter in the wooden blocks and sticks having small entrance or pithy regions (1-2 mm diameter) were occupied mostly by the aphid wasps (Carinostigmus costatus Krombein). Bigger holes were occupied by other species of wasps, viz. Crabronids (Pison sp., C. costatus, Parancistrocerus sp., Ectemnius sp.) and Sphecids (Chalybion bengalense Dahlbom, Chalybion sp., Trypoxylon petiolatum Smith). Nests of Pison sp., Parancistrocerus sp., Carinostigmus costatus and $T$. petiolatum were more compared to other wasps (Table 1). Upon dissection, nests of the wasps had paralysed aphids (C. costatus) or spiders (other wasp species) which were provisioned by them for their young ones. These wasps neither disturbed the activities of Braunsapis bees in the nest nor predated them during regular observations. Yet, occupancy by all these wasps was less than $25 \%$ of the total nest holes at any time.

A study in Brazil indicated that bamboo stem sections and cardboard tubes inserted into drilled wooden blocks were occupied by many bee species including Centris spp., Tetrapedia spp., Eufriesea spp., Euglossa sp., Megachile spp. and Colletes sp. ${ }^{18}$. Similarly, studies conducted in Europe and South America indicated successful occupation of bees, fully or partially, in reed stems, followed by wooden blocks with manually drilled holes and bamboo stems, mainly Osmia sp., Anthidium sp., Heriades sp., Megachile sp. and Duckeanthidium sp. The number of solitary bee species recorded ranged from 11 to 33 in these studies ${ }^{16}$. In the present study, occupation only by Braunsapis spp. was noticed, which might be due to its preference for the nest hole sizes tested and the nesting substrate used. Similarly, Osmia rufa was the only species found to occupy any of the tin cans filled with paper drinking straws ${ }^{19}$.

Occupancy of Braunsapis spp. gradually increased over the months. In general, activity of bees near the nest vicinity was more during January to April, which coincides with the flowering season of many crops, including cashew when compared to the rainy season. However, no marked difference in per cent occupancy of nests by the bees was recorded between flowering and non-flowering seasons of cashew. Among the two Braunsapis species occupying the nests, $B$. mixta was dominant $(86 \%)$. Three years of observations indicated that occupancy by bees had increased over time in all nest hole sizes (Figure 4). However, nest hole size of $3 \mathrm{~mm}$ diameter was highly preferred by both the bee species followed by $2.5 \mathrm{~mm}$ and $3.5 \mathrm{~mm}$ diameter. Out of 415 holes of $3 \mathrm{~mm}$ diameter, $32.77 \%$ was occupied during 2018 , which increased to $54.70 \%$ and $62.65 \%$ in 2019 and 2020 respectively (Figure 4). During 2018, out of the total nest holes occupied, $80 \%$ was $3 \mathrm{~mm}$ diameter and $14.71 \%$ was of $2.5 \mathrm{~mm}$ diameter (Figure 5). During 2019 and 2020 also, significantly high occupancy percentage was recorded in $3 \mathrm{~mm}$ diameter holes $(70.28 \%$ and 


\section{RESEARCH ARTICLES}

$65.16 \%$ respectively), followed by $2.5 \mathrm{~mm}$ diameter holes (17.34\% and $16.04 \%$ respectively; $P<0.001 \%$ ).

These artificial nests helped to record important nesting behaviour of these bee species as documented here. The cylindrical wooden blocks having two different nest hole sizes at its flat ends had high occupancy by bees in $3 \mathrm{~mm}$ diameter holes at one end, while extremely poor occupancy by bees but more wasps in the $4 \mathrm{~mm}$ diameter holes at the opposite end (Figure $2 a$ and $b$ ). This confirms that the diameter of holes is an important factor for these native bees than the nature of wood. The observations indicated that both bee species gradually occupied nest holes that were previously occupied by wasps or its abandoned nests. Bees were commonly observed at the entrance holes made in old mud seals of wasps, in this way they could occupy larger-sized holes also (Figure $6 a$ ). The occupied bamboo sticks when split open revealed eggs, larvae of developing stages, pupae and adults of bee species were found close to each other at the deeper end of nest without any partitions. The number of individuals per bamboo stick varied from 1 to 31 for B. mixta and from 1 to 16 for B. picitarsis. The observations on nest mates over two years indicated that all brood stages were present throughout the year for both bee species. Recording their life cycle under laboratory conditions was difficult as the larva period was long (remained alive without food for nearly 10 days at the same stage); they are progressively fed by the adults.

Both Braunsapis spp. preferred to occupy pre-existing burrows or holes as more occupancy was found in bamboo sticks. Among the sticks, bamboo was preferred

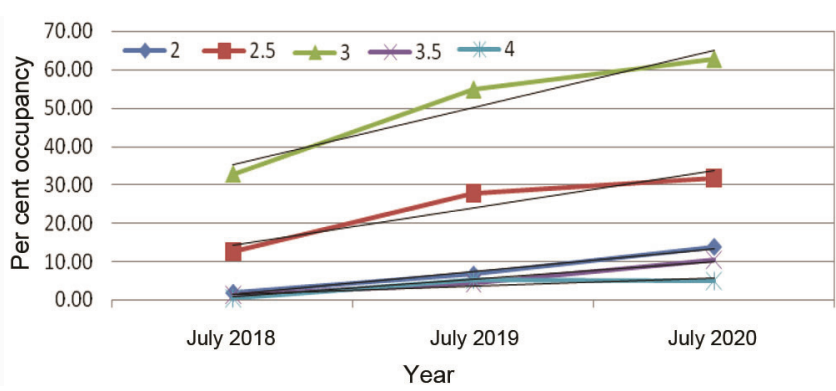

Figure 4. Per cent nest occupancy of Braunsapis spp. in specific nest diameters over the years.

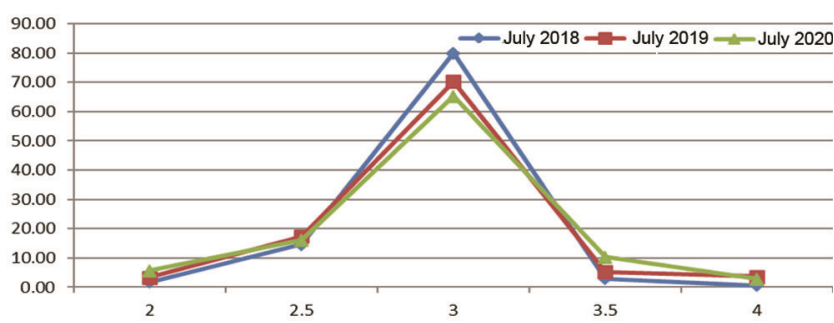

Figure 5. Per cent occupancy of Braunsapis spp. to total nests over the years. by the bees $(75 \%$ occupancy of total bamboo sticks by B. mixta and $5 \%$ by B. picitarsis). Occupancy was $47 \%$ and $3 \%$ for sticks of Johnson's grass, $33 \%$ and $2 \%$ for lantana sticks, and $9 \%$ and $1 \%$ for cashew sticks by B. mixta and B. picitarsis respectively. Bees occupied bamboo sticks with cavity length even up to $25.6 \mathrm{~cm}$. Observations also indicated that these bees can make their own nest burrows by excavating the soft pith in cut stems, which was evident by the presence of excavated pithy particles outside the sticks of lantana, cashew and Johnson's grass. Nest constrictions at the entrance made of compacted wood particles were invariably noticed in large-sized holes $(3,3.5$ and $4 \mathrm{~mm}$ diameter in wooden blocks). As in wooden blocks, both bee species also occupied old nests of crabronids and sphecids in bamboo sticks by making a fresh partition before the dead/ abandoned/emerged wasp cells and occupying the remaining space. Further, this nest set-up can also be a useful tool to understand few aspects of these species like seasonal activity, breeding season, bee flora, etc. based on fecal pellets, dried pollen and debris seen outside the nest entrance (Figure $6 b$ ).

These artificial nests also helped to document few natural enemies of $B$. mixta, which could have been unnoticed under natural conditions. For example, on three occasions, a female Torymid wasp was seen at the entrance of the nest, slowly approaching the guarding bees, palping the abdomen, bending the abdominal tip and trying to oviposit on the guarding bee. In addition, bees with torn abdomen, and body parts along with pupae of Conopid flies were seen outside the nests. In three bees, pupa of the conopid was seen inside the abdomen of $B$. mixta confirming the flies are parasitoids of $B$. mixta (Figure $7 \mathrm{~b}$ and $c$ ). Adult flies of Conopidae emerged after 12-16 days from the pupae kept in petri plates under laboratory. Reports are available on parasitism of Conopid flies on different bees like Xylocopa sp., Bombus sp., Eulaema sp. and Centris sp. as well as wasps ${ }^{20-23}$. Conopid flies (Conopidae, Diptera) are prevalent endoparasitoids of bees

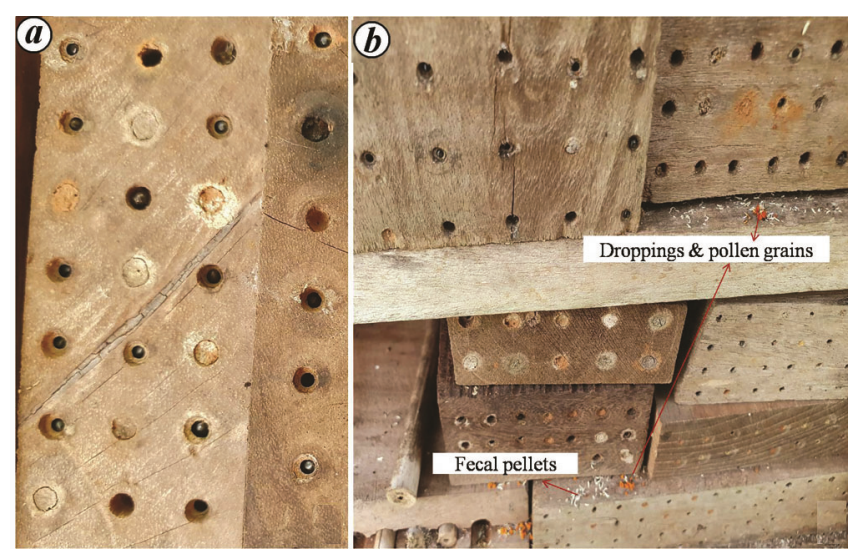

Figure 6. $\boldsymbol{a}$, Bees occupying wasp nests (mud sealing). b, Fecal pellets and pollen grains outside the nest entrance. 

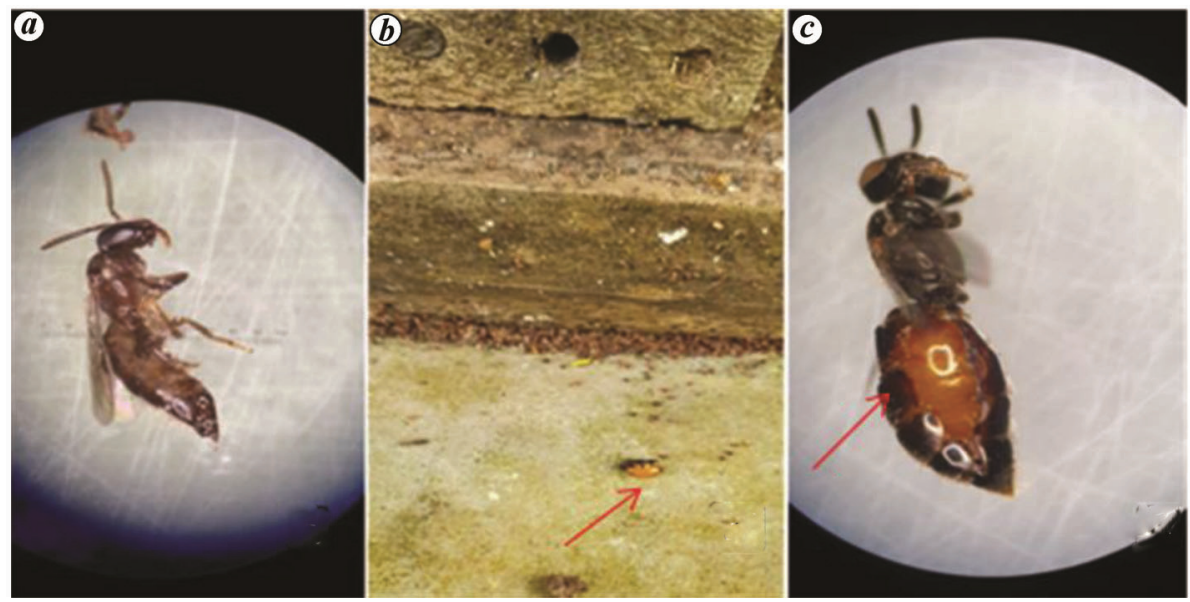

Figure 7. Parasitoids of B. mixta. a, Braunsapis kaliago. b, Conopid pupa outside the nest. $c$, Conopid pupa inside the abdomen of female B. mixta.

and wasps, often infecting a high percentage of freeflying individuals. Conopids can reduce worker lifespan and foraging efficiency; consequently, they may negatively affect colony success ${ }^{24}$. Specimens of Conopid flies have been preserved for species-level identification.

Periodical observations on nest mates in the sticks helped document the presence of a parasitic bee species, Braunsapis kaliago Reyes and Sakagami inside the nests of $B$. mixta (Figure $7 a$ ), which was present in $1.7 \%$ of nests examined $(x=172)$. In $B$. kaliago, T6 is scoopshaped and scopa is reduced. Cuckoo wasps (Chrysis listis; Chrysipidae) were also seen near the nests, but their target is presently unknown as these wasps were also occupants in a few nest holes. The cuckoo wasps are considered as cleptoparasitic bees, as they do not construct nests, but lay their eggs in the nests of other bees so that these eggs can hatch and steal the food and the nest, therefore they are referred to as cuckoo bees as well ${ }^{24}$. A study revealed that due to mould and parasitism, plastic-lined tubes were not favourable in terms of nest success and sustainability for $O$. rufa, though high occupancy nest rate of $80 \%-100 \%$ was found initially ${ }^{25}$. Details on parasitism in this study were recorded only with B. mixta and not on B. picitarsis, which may be due to their less numbers.

\section{Conclusions}

The present study proves that artificial nests provided for the native bees, Braunsapis spp. showed high occupancy rates by $B$. mixta followed by $B$. picitarsis. Thus, these native bee species that are in favour of nesting and conservation efforts should be promoted extensively to increase the availability of artificial nesting sites for these bees in cashew plantations. These artificial nesting structures can be useful tools to study life history and ecological aspects of these bee species, besides serving as a tool to sustain and increase their population in the study region. Further research needs to be conducted at specific sites to collect more comprehensive information on the design of artificial nests, preferred materials, habitat location and the bee species being benefitted.

1. Roubik, D. W. and Roubik, D. W., Pollination of cultivated plants in the tropics. Food Agricultural Organisation, UN, Rome, Italy, 1995.

2. Danforth, B. N., Sipes, S., Fang, J. and Brady, S. G., The history of early bee diversification based on five genes plus morphology. Proc. Natl. Acad. Sci. USA, 2006, 103, 15118-15123.

3. Kremen, C., Williams, N. M. and Thorp, R. W., Crop pollination from native bees at risk from agricultural intensification. Proc. Natl. Acad. Sci. USA, 2002, 99(26), 16812-16816; https://doi.org/ $10.1073 /$ pnas.262413599.

4. Potts, S. G., Vulliamy, B., Roberts, S., O’Toole, C., Dafni, A., Ne'eman, G. and Willmer, P. A. T., Role of nesting resources in organising diverse bee communities in a Mediterranean landscape. Ecol. Entomol., 2005, 30, 78-85; doi:10.1111/j.0307-6946. 2005.00662.x.

5. Potts, S. G., Vulliamy, B., Dafni, A., Ne'eman, G., O'Toole, C., Roberts, S. and Willmer, P. G., Response of plant-pollinator communities following fire: changes in diversity, abundance and reward structure. Oikos, 2003, 101, 103-112.

6. Bayo, S. F. and Wyckhuys, K. A., Worldwide decline of the Entomofauna: a review of its drivers. Biol. Conserv., 2019, 232, $8-27$.

7. National Research Council, Status of Pollinators in North America, The National Academies Press, Washington, DC, USA, 2017; https://doi.org/10.17226/11761.

8. Rhodes, C. J., Pollinator decline - an ecological calamity in the making? Sci. Progr., 2018, 101(2), 121-160; doi:10.3184/ 003685018x15202512854527; ISSN 0036-8504.

9. Cane, J. H., A native ground-nesting bee (Nomia melanderi) sustainably managed to pollinate alfalfa across an intensively agricultural landscape. Apidologie, 2008, 39, 315-323.

10. Sardinas, H. S. and Kremen, C., Evaluating nesting microhabitat for ground-nesting bees using emergence traps. Basic Appl. Ecol., 2014, 15, 161-168; doi:10.1016/j.baae.2014.02.004.

11. Vanitha, K. and Raviprasad, T. N., Diversity, species richness and foraging behaviour of pollinators in cashew. Agric. Res., 2019, 8(2), 197-206; doi:10.1007/s40003-018-0370-2. 
12. Prasantha, C., Taxonomic studies on carpenter bees (Hymenoptera: Apidae: Xylocopinae) of Karnataka. Ph D thesis, Department of Agricultural Entomology, University of Agricultural Sciences, GKVK, Bengaluru, 2017.

13. ICAR-DCR, Annual Report (eds Shamsudheen, M., Siddanna Savadi and Mohana, G. S.), ICAR-Directorate of Cashew Research, Puttur, 2018.

14. Richards, K., Comparisons of nesting materials used for the alfalfa leafcutter bee, Megachile pacifica (Hymenoptera: Megachilidae). Can. Entomol., 1978, 110, 841-846.

15. Thiele, R., Phenology and nest site preferences of wood-nesting bees in Neotropical lowland rain forest. Stud. Neotrop. Fauna Environ., 2005, 40, 39-48.

16. Dicks, L. V., Showler, D. A. and Sutherland, W. J., Bee Conservation: Evidence for the Effects of Intervention, Pelagic Publishing, UK, 2010.

17. Fortel, L., Henry, M., Guilbaud, L., Mouret, H. and Vaissière, B. E., Use of human-made nesting structures by wild bees in an urban environment. J. Insect Conserv., 2016, 20, 239-253.

18. Gazola, A. L. and Garófalo, C. A., Trap-nesting bees (Hymenoptera: Apoidea) in forest fragments of the State of São Paulo, Brazil Genet. Mol. Res., 2009, 8, 607-622.

19. Gaston, K. J., Smith, R. M., Thompson, K. and Warren, P. H., Urban domestic gardens (II): experimental tests of methods for increasing biodiversity. Biodiver. Conserv., 2005, 14, 395-413.

20. Clements, D. K., The enemy within - conopid flies as parasitoids of bees and wasps in Britain. Br. Wildl., 1997, 8(5), 310-315.

21. Rasmussen, C. and Cameron, S. A. Conopid fly (Diptera: Conopidae) attacking large orchid bees (Hymenoptera: Apidae: Eulaema). J. Kansas Entomol. Soc., 2004, 77(1), 61-62.

22. Lucia, M., Aquino, D. A., Hansson, C. and Abrahamovich, A. H., The first record of conopid flies (Diptera: Conopidae) and eulophid wasps (Hymenoptera: Eulophidae) as parasitoids and hyperparasitoids associated with carpenter bees (Apidae: Xylocopinae) in $\mathrm{Ar}$ gentina. J. Apicult. Res., 2009, 49(2), 208-211; doi:10.3896/ IBRA.1.49.2.11.

23. Malfi, R. L., Walter, J. A., Roulston, T. H., Stuligross, C., McIntosh, S. and Bauer, L., The influence of conopid flies on bumble bee colony productivity under different food resource conditions. Ecol. Monogr., 2018, 88(4), 653-671; https://doi.org/10.1002/ ecm.1327.

24. Wcislo, W. T., The roles of seasonality, host synchrony, and behaviour in the evolution and distribution of nest parasites in Hymenoptera (Insecta) with special reference to bees (Apoidea). Biol. Rev., 1987, 62(4), 515-543.

25. Wilkaniec, Z. and Giejdasz, K., Suitability of nesting substrates for the cavity-nesting bee Osmia rufa. J. Apicult. Res., 2003, 42, 29-31.

ACKNOWLEDGEMENTS. We thank Dr Arati Pannurae (College of Sericulture, University of Agricultural Sciences (UAS), GKVK, Bengaluru) for identifying the bee species and parasitic bee species. First author thanks Dr H. M. Yeshwanth (UAS, GKVK, Bengaluru) for identifying different wasp species. We also thank the Director, ICARDirectorate of Cashew Research, Puttur for support. First author also thanks Mr Vijay Achary (ICAR-Directorate of Cashew Research, Puttur) for help in devising the artificial nest structure.

Received 19 January 2021; revised accepted 15 March 2021

doi: $10.18520 / \mathrm{cs} / \mathrm{v} 121 / \mathrm{i} 1 / 127-132$ 